Ann. Biol. anim. Bioch. Biophys., I975, 15 (2), I8I-I9o.

\title{
ROLE OF PROSTAGLANDINS IN FOLLIGULAR RESPONSES TO LUTEINIZING HORMONE
}

\author{
D. T. ARMSTRONG (1) \\ Department of Obstetrics and Gynaecology, \\ Department of Physiology, \\ University of Western Ontario, \\ London, Ontario (Canada)
}

\begin{abstract}
SUMMARY
Levels of prostaglandins of the $\mathrm{F}$ series have been found to increase several-fold during the pre-ovulatory period in follicles of rabbits, rats, and swine, reaching maximal levels shortly before ovulation. In rabbits and rats, the increase can be induced by exogenous luteinizing hormone $(\mathrm{LH})$. The increase in rats is preceded by increases in ovarian levels of cyclic AMP and progesterone. Systemic administration of indomethacin prevented the increase of ovarian prostaglandin $\mathrm{F}$ and blocked ovulation in rabbits and rats. Intrafollicular injection of indomethacin, in rabbits, at dosages which were ineffective when given via systemic injection, blocked the elevation of follicular prostaglandins and ovulation. Prostaglandin $\vec{F}_{2 \alpha}$ antiserum also blocked LH-induced ovulation when injected intrafollicularly. Intrafollicular injection of prostaglandin $F_{2 \alpha}$, in rabbits in the absence of $\mathrm{LH}$ resulted in release of ova from $40 \mathrm{p}$. Ioo of injected follicles, and in resumption of meiotic division of oöcytes in $90 \mathrm{p}$. 100 of injected follicles. Prostaglandin $E_{2}$ was much less effective. These results provide evidence in support of a physiologic role of follicular prostaglandin $\mathrm{F}_{2 \alpha}$ in the process of ovulation and oöcyte maturation in response to $\mathrm{LH}$.
\end{abstract}

\section{INTRODUCTION}

Prostaglandins have been implicated, on the basis of in vitro studies, as playing an intermediate role in the mechanism by which luteinizing hormone $(\mathrm{LH})$ activates ovarian adenylate cyclase, thereby stimulating steroid biosynthesis (KUEHL et al., I970). Subsequently, a considerable body of evidence has been accumulated, suggesting roles of prostaglandins in three additional ovarian responses to $\mathrm{LH}$, viz. orulation (Armstrong and Grinwich, I972; OrCZyK and BEHrman, I972; Grinwich, KENNEDy and ARMSTRONG, I972), oocyte maturation (TSAFrIRI et al., I972; ARMS-

(1) Associate of the Medical Research Council (Canada). 
trong, MoOx and Zamecnik, I974), and luteinization (Kolena and Channing, I972; EIILSWORTH and ARMSTRONG, I974). This paper reviews recent in vivo evidence bearing on the possible involvement of prostaglandins in each of these follicular responses to $\mathrm{L} H$.

\section{EXPERIMENTAL}

\section{I. - Pre-ovulatory changes of ovarian prostaglandin $F$ levels Correlation with other ovarian responses to $L H$}

A) Rats.

Ovarian prostaglandin F (PGF) levels have been measured by radioimmunoassay, at various times in relation to ovulation in prepubertal rats in which first estrus has been induced prematurely by injection of pregnant mare serum gonadotropin (PMS) (ARMSTRONG and ZAMECNIK, I975). As summarized in figure I, ovarian PGF

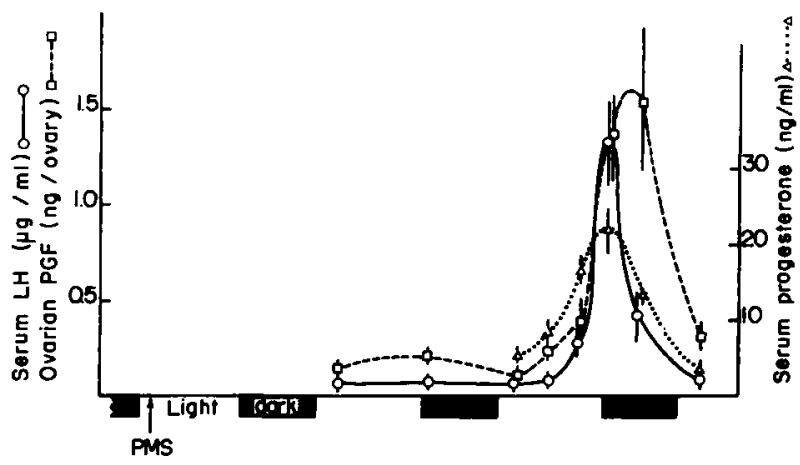

I'IG. I. - Proestrous elevation of serum LH, serum progesterone and ovarian prostaglandins $F$ in prepubertal rats in which first estrus and ovulation was induced by injection of 4 IU PMS at 28 days of age. Rats were on lighting schedule of I 4 hours light : ro hours dark, with lights on at o7oo. Serum LH levels, measured by radioimmunoassay (RIA), are expressed in terms of NIAMD-Rat LH-RPI reference preparation. Progesterone was measured in unfractionated petroleum ether extracts, of serum, by RIA using an antiserum against Progesterone-6-BSA supplied by Dr. Gordon Niswender. Prostaglandins of the F series were measured in unfractionated ethanolic extracts of whole ovaries using an antiserum prepared against a prostaglandin $\mathrm{F}_{2 \alpha}$-BSA conjugate donated by Dr. Harold R. BEHRMAN. Points on curves are means of at least 4 animals $\pm S$. E.

levels became elevated, approximately in parallel with serum levels of LH or progesterone measured in the same rats; ovarian PGF reached apparently maximal levels shortly before orulation. Similar elevations of ovarian PGF levels were found following i.r. or i.p. injections of exogenous LH, after a lag period of about 2 hours (fig. 2 ) (ARMSTRong, Robinson and Dorrington, unpublished observations). In the same animals, ovarian levels of progesterone and cyclic adenosine-3', 5'-monophosphate (cAMP) were observed to increase much more rapidly. The time-courses of these three ovarian responses to $\mathrm{L}_{\mathrm{H}} \mathrm{H}$ are consistent with the well-established concept of CAMP being a mediator of the steroidogenic action of $\mathrm{I}_{\mathbf{H}} \mathrm{H}$, but argue against PGF as an obligatory intermediate in either of the other responses. 

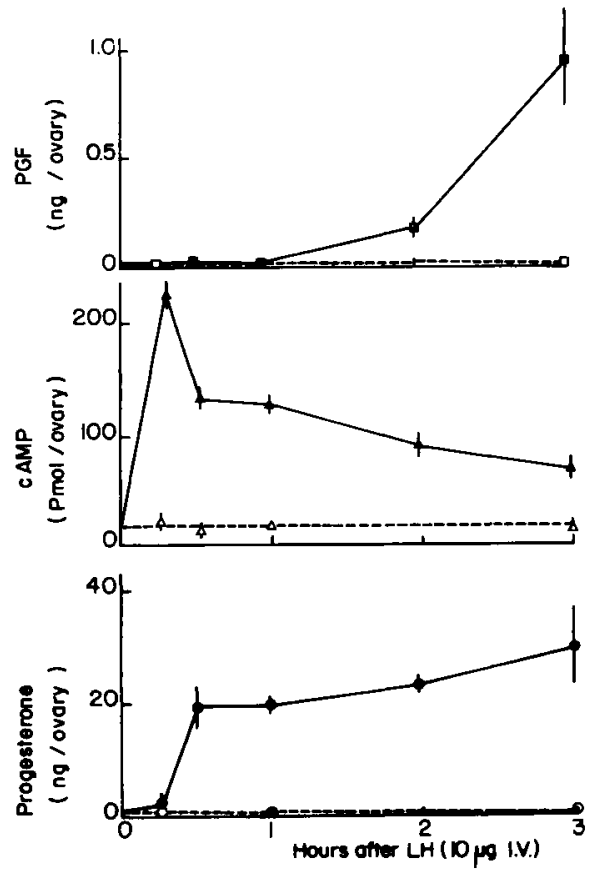

FIG. 2. - Ovarian lewcls (means $\pm \mathrm{S}$. E.) of PGF, cAMP and progesterone on the second day after P.MS treatment of prepubertal rats (as in fig. $\mathrm{I}$ ), at varying times after i.v. injection at $0730-0800$ of 0.9 p. $100 \mathrm{NaCl}$

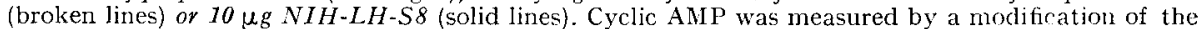
protein-binding assay of GILMax (1970).

B) Rabbits.

The effects of endogenous (coitus-induced) and exogenous LH on levels of PGF measured in rabbit Graafian follicles are summarized in figure 3 (7AMEcrik and Armstrong, 1973). As in rat ovaries, no significant elevation of PGF was noted one hour aftrer $\mathrm{L}_{4} \mathrm{H}$ (exogenous or endogenous), whereas PGF levels were increased severalfold 8 hours later (i.e., approximately one hour before expected ovulation). Similar elevations of PGF as well as prostaglandin $\mathrm{E}$ (PGE) in rabbit follicles following human chorionic gonadotropin (HCG) injection have been reported by LE MAIRE et al. (I973).

C) Swine.

Prepubertal gilts have been injected with a combination of PMS and HCG in order to synchronize estrus and induce ovulation. Follicular fluid was aspirated from large surface follicles, via laparotomies performed at varying times from 64 to II 5 hours after the combined PMS-HCG treatment (AINSwORTH, BAKER and ARMSTRONG, I975). As summarized in figure 4, follicular fluid concentrations of PGF became significantly elevated by Ioo hours and reached levels 30 times basal values by I 3 hours in follicles ascertained on the basis of morphologic characteristics as being pre-ovulatory. No significant elevations of PGF levels were noted in fluid from atretic follicles sampled at the same times. In this experimental model, ovulation normally occurs at II $6 \pm 8$ hours after PMS-HCG treatment (R. D. BAKER, personal communication). 


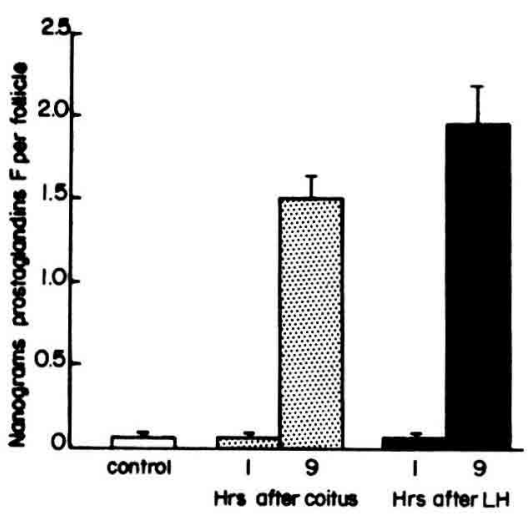

FIG. 3

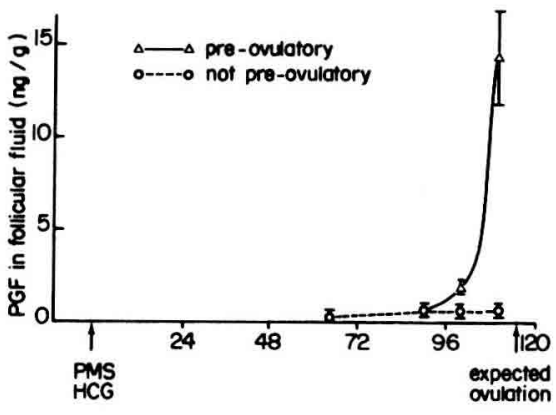

FIG. 4

FIG. 3. - Elevation of $P G F$ levels (mean \pm S. E.) in follicles of estrous rabbits, induced by coitus and by exogenous $L H$ (50 $\mu \mathrm{g} \mathrm{NIH-LH-B7}$ i.v.) (data from Armstrong, Moon and ZAMECNIK, I974)

I'IG. 4. - Pre-ovulatory elevation of follicular fluid prostaglandins $F$ (mean \pm S. E.) in prepubertal gilts. First estrus was synchronized by a single $\mathrm{i}$. $\mathrm{m}$. injection of 400 IU PMS combined with 200 IU HCG at 5-6 months of age. Follicles sampled at 99-10I hours and I Io-II 3 hours after PMS-HCG could be classified according to gross morphological appearance and vascularity as either pre-ovulatory $(\Delta-\Delta)$ or not pre-ovulatory $(0 . . .-0)$ (data from Ainsworth, BAKER and ARMSTrong, 1975).

\section{II. - Blockade of pre-ovulatory elevations of ovarian prostaglandin $F$ levels; effects on other ovarian responses to $L H$}

A) Rats.

Indomethacin, an established inhibitor of prostaglandin synthetase (VANE, I97I), was administered systemically to rats at I445 on the second day following PMS treatment of prepubertal rats-i.e., approximately I-3 hours before the expected LH surge (ARMSTRONG and ZAMECNIK, I975). Another group of animals was injected with barbital, an established inhibitor of $\mathrm{L} / \mathrm{H}$ secretion, at approximately the same time. As summarized in figure 5 , both indomethacin and barbital completely prevented the expected increases in levels of $\mathrm{PGF}$, in ovaries obtained at autopsies performed at 2030-2100. In the barbital-treated rats, the expected elevations of serum LH and serum progesterone were completely suppressed, whereas indomethacin caused no significant reduction in the levels of either of these hormones (fig. 6).

Meiosis in the large Graafian follicles of control rats autopsied at 2030-2100 was found to have proceeded to metaphase $I$ or beyond. This resumption of meiosis (oöcyte maturation) was prevented by barbital treatment, but not by indomethacin treatment (fig. 5) (ARMSTRONG, unpublished observation). A similar failure of indomethacin to prevent oöcyte maturation in adult rats on proestrus has been reported by TSAIRIRI, KOCH and LINDNER (I972).

Both indomethacin and barbital effectively blocked ovulation. No tubal ova nor follicle rupture points were noted in rats killed at ogo0-I I00 on the third day after PMS treatment, whereas $8.7 \pm 0.7$ ova were found in the oviducts of control rats autopsied at the same time. 


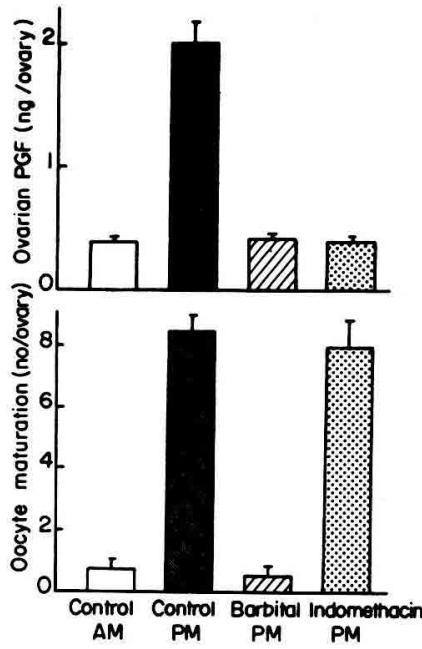

FIG. 5
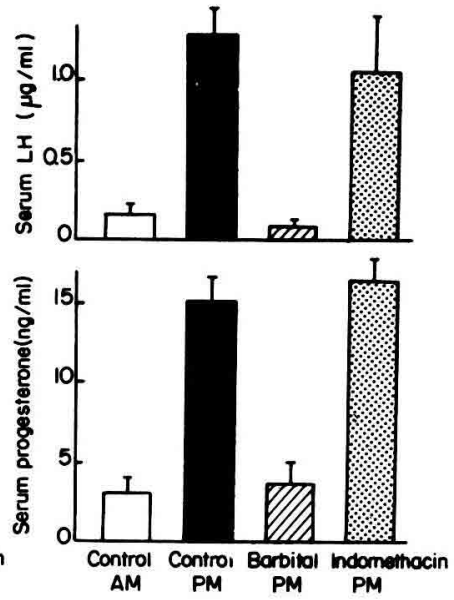

FIG 6.

Jiri. 5. - Effects of barbital (Io $\mathrm{mg} / \mathrm{rat}$ ) and indomethacin (o.8 $\mathrm{mg} / \mathrm{rat}$ ) on proestrous ovarian prostaglandin F levels and on oöcyte maturation in prepubertal rats. Autopsies were performed at I ooo- I ozo (AM) and at 2030-2Ioo (PM) on the second day following PMS injection to synchronize first estrus (as in fig. I). Barbital and indomethacin were administered by i.p. injection at 1345 and I 445 respectively, on the same day. Oöcyte maturation was determined in follicles of pre-ovulatory size by histological examination of serial sections of ovaries.

IIG. 6. -- Effects of barbital and indomethacin on proestrous elevations of serum LH and serum progesterone. in prepubertal rats in which first estrus was synchronized with PMS (as in fig. I). Drug administrations and autopsies were as in figure 5 .

TABLE I

Peripheral plasma progesterone ${ }^{(1)}$ in rabbits during pseudopregnancy following blockade of $\mathrm{LH}$-induced ovulation by indomethacin

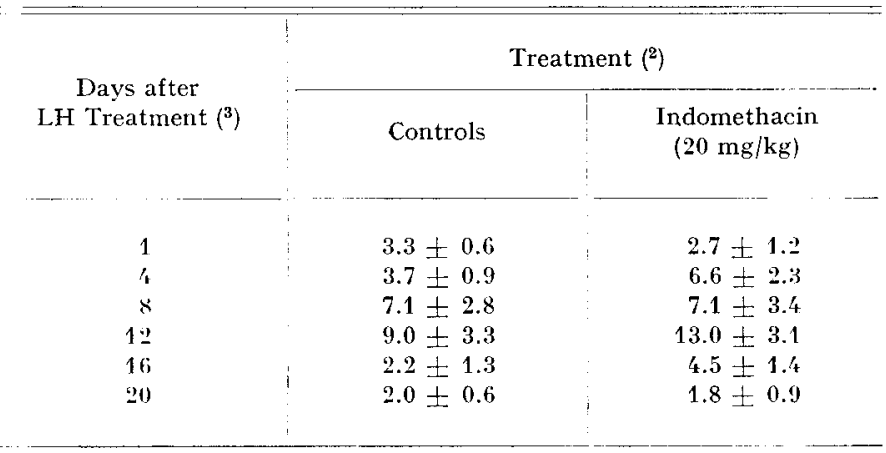

(1) Progesterone (Mean $\mathrm{ng} / \mathrm{ml}$ plasma \pm S. E.) measured by radioinmunoassay.

$\left({ }^{2}\right)$ Treatment administered i. v. in $0.1 \mathrm{M}$ phosphate buffer, $\mathrm{pH} 8.0$, $1 / 2$ hour before injection. 5 rabbits per treatment.

( $\left.{ }^{3}\right) 50 \mu \mathrm{g}$ NIH-LH-B7 i. v. to induce ovulation and/or pseudopregnancy. 
B) Rabbits.

Indomethacin, when injected $\mathrm{I} / 2$ hour before, or up to five hours after injection of an otherwise ovulatory dose of LH to estrous rabbits, has been reported to prevent ovulation (fig. 7) (Grinwich, and Kennedy Armstrong, I972). Despite the blockade of ovulation, corpora lutea formed which appeared normal histologically (Armstrong, Moon and Grinwich, I973), and maintained normal serum levels of progesterone during the resulting pseudopregnancy (table I).

Intrafollicular injection of a much smaller dose of indomethacin has been found almost equally as effective as $20 \mathrm{mg} / \mathrm{kg}$ administered systemically, in blocking ovulation (fig. 8) (ARMSTRONG et al., I974). Control follicles injected intrafollicularly with the phosphate buffer vehicle ovulated normally. As summarized in figures 7 and 8 , the ovulation-blocking dosages of indomethacin administered via the i.v. or intrafollicular routes were effective in suppressing the elevations of follicular PGF.

Intrafollicular injections of antiserum prepared against $\mathrm{PGF}_{2 \alpha}$ have been found as effective as indomethacin in blocking ovulation when injected 5 hours after an ovulation-inducing dosage of LH (ARMSTRONG et al., I974). Most control follicles injected with either normal rabbit serum, or antiserum against $\mathrm{PGE}_{2}$ underwent normal ovulation.

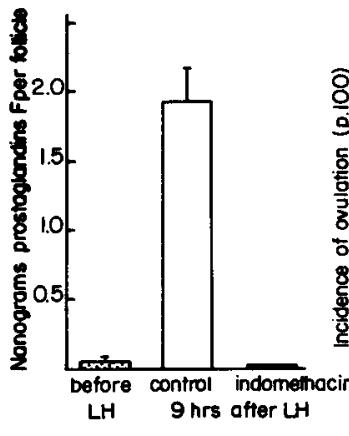

Fig. 7

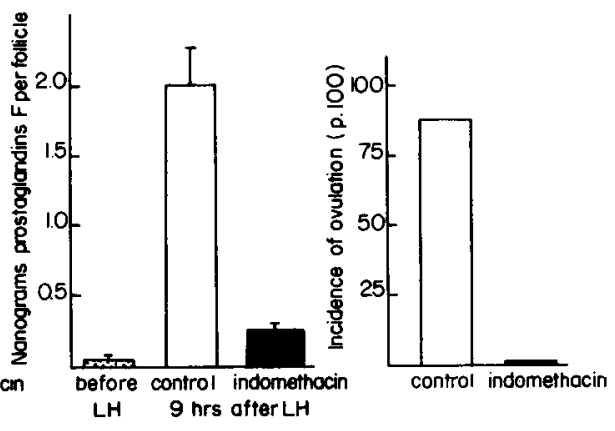

FIG. 8

FIG. 7. - Blockade of elevation of prostaglandin F levels in rabbit follicles and of ovulation by systemic injection of indomethacin, $20 \mathrm{mg} / \mathrm{kg}$ s. c. immediately before $i . v$. injection of $50 \mu \mathrm{g} N I H-L H-B$. Rabbits were killed 9 hours after LH for PGF determinations and approximately 24 hours after LH to determine incidence of ovulation, as described by Grinwich, Kennedy and Armstrong (1972).

Fig. 8. - Blockade of elevation of prostaglandin $F$ levels in rabbit follicles and of ovulation by intrafollicular injections of $5 \mu \mathrm{g}$ indomethacin in $1 \mu \mathrm{l}$ of $0.15 \mathrm{M}$ phosphate buffer 5 hours after i.v. injection of $50 \mu \mathrm{g}$ $N I H-L H-B 7$. Control follicles on the opposite ovaries of the same rabbits were injected with $I \mu l$ of the phosphate buffer vehicle. Autopsy times were as for figure 7. Data from ArmstrosG, Grinwich, MOON and ZAMECNIK, I974.

\section{III. - Effect of intrafollicular injections of $\mathrm{LH}$}

and prostaglandins on ovulation and oocyte maturation

Luteinizing hormone has been reported previously (JoNEs and NALBANDov, I972) to induce ovulation when injected directly into the follicles of estrous rabbits. In order to confirm this action, and to determine whether this response could be mimicked by exogenous prostaglandins, $\mathrm{LH}, \mathrm{PGE}_{2}$ and $\mathrm{PGF}_{2 \alpha}$ were injected intrafollicularly. Ovaries were removed $4,8, \mathrm{I} 2$ or 24 hours later and examined grossly and histologically for evidence of ovulation, and histologically for evidence of oöcyte 
maturation. As shown in table 2 (Armstrong, Moon and Zamecnik, I974), LH was highly effective in inducing what appeared to be normal follicular rupture at the apices of 6 of the 13 follicles injected. The oöcytes from 2 additional LH-injected follicles were found, on serial sectioning of the ovaries, outside the follicles, within the ovarian stroma adjacent to the points of the micro-injections of the follicles.

TABLE 2

Effects of intrafollicular injections of prostaglandins and LH on ovulation and oöcyle maturation

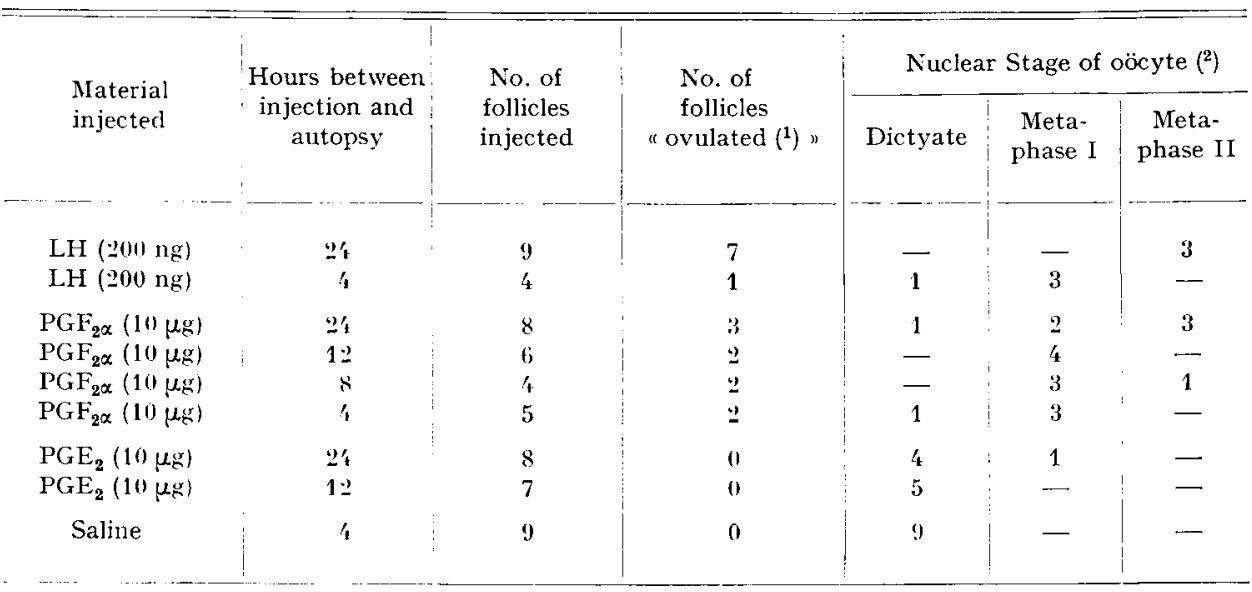

(1) Oöcytes extruded either through apical rupture point and not recovered, or extruded through point of injection and recovered within ovarian stroma (see text).

${ }^{(2)}$ Oöcytes recovered either in ovarian stroma (outside follicles) or retained within injected follicles.

TABLE 3

Effects of intrafollicular injection of prostaglandin $F_{2 x}$ in varying amounts on ovum extrusion in rabbits

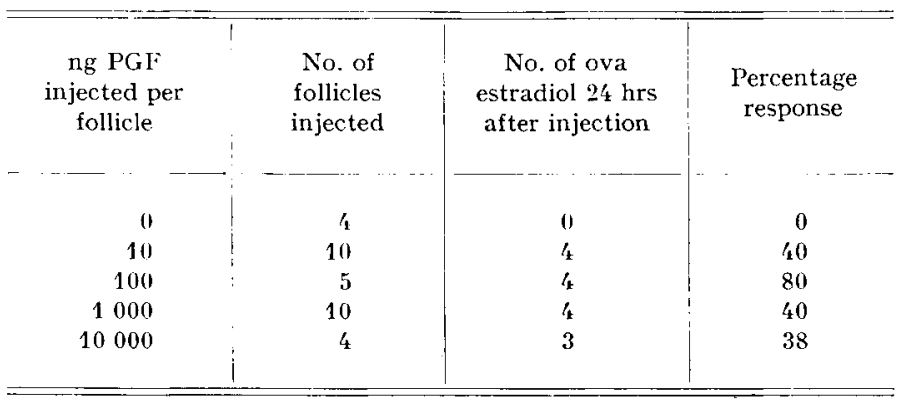

Meiosis had resumed in these oöcytes, as well as in those recovered within 5 nonruptured follicles which had been injected with $\mathrm{LH}$. Of the 23 follicles injected with $\mathrm{PGF}_{2 \alpha}, 9$ were observed to have extruded their oöcytes through the points of injec- 
tions, in a manner similar to that of the latter two $\mathrm{LH}$-injected follicles. None underwent " normal " ovulation through apical stigmata. Meiosis had resumed in eight of these extruded ova, as well as in eight of those still retained within the remaining $\mathrm{PGF}_{2}{ }$-injected follicles. None of the oöcytes was extruded from $\mathrm{I}_{5} \mathrm{PGE}_{2}$-injected follicles or from 9 saline-injected follicles, and only one oöcyte in a PGE -injected $_{2}$ follicle had progressed beyond the dictyate stage of meiosis.

A comparison of varying dosages of $\mathrm{PGF}_{2 \alpha}$ (table 3 ), revealed that intrafollicular injection of as little as Io ng were approximately as effective in causing ovum extrusion as were the high dosages used in the experiments summarized in table 2 .

\section{DISCUSSION}

In the studies reviewed above, four types of evidence have been obtained, suggesting a role of $\mathrm{PGF}_{2 . x}$ in the process of ovulation as follows : I) Levels of PGF have been observed to increase markedly in rat ovaries and in rabbit and pig follicles shortly before ovulation. 2) Pharmacologic inhibition of prostaglandin synthesis in rats and rabbits, thereby preventing the expected pre-ovulatory increases in follicular PGF, was associated with blockade of ovulation. 3) Antiserum against $\mathrm{PGF}_{2 \alpha}$ blocked ovulation when administered via micro-injection directly into preovulatory follicles of estrous rabbits. 4) Intrafollicular injection of $\mathrm{PGF}_{2 x}$, in the absence of $\mathrm{LH}$ treatment, caused extrusion of ova from a significant number of injected follicles of estrous rabbits.

The effectiveness of $\mathrm{PGF}_{2 \alpha}$ to induce oöcyte maturation suggests that this prostaglandin may be involved in the resumption of meiosis, in response to $\mathrm{LH}$. Prostaglandin $E_{2}$ was essentially ineffective in this regard, in contrast to its effectiveness in the organ culture studies of TSAFRIRI et al. (I972), using rat follicles. These observations are difficult to reconcile with the observations reported here, as well as with those of TSAFRIRI, KOCH and LINDNER (I972), that LH-induced orum maturation in vivo is not blocked by indomethacin at dosages effective in suppressing PGF synthesis and in blocking ovulation. It is possible that considerably smaller increments in follicular prostaglandin levels are required for ovum maturation than for ovulation, and that indomethacin does not completely prevent the required small increases from occurring.

The time-course of elevations of ovarian PGF, cAMP and progesterone following exogenous $\mathrm{L} H$ administration to proestrous rats indicates that the latter two responses occur considerably earlier than does the increased PGF synthesis. The rapid increase in cAMP levels, followed promptly by elevation of ovarian progesterone concentration, supports the "second messenger " role of this cyclic nucleotide in stimulation of steroidogenesis. The delayed elevation of ovarian PGF concentration makes it unlikely that PGF is involved in the mechanism by which $\mathrm{L}_{1} \mathrm{H}$ activates adenylate cyclase; an alternative possibility is that increased PGF synthesis may be a consequence of elevated cAMP and/or steroid levels.

The mechanism by which prostaglandins lead to ovulation remains uncertain. One possibility is that a contractile proces mediated by $\mathrm{PGF}_{2 \alpha}$, contributes to rupture of the follicle wall after it has become distended and weakened by proteolytic 
digestion in response to $\mathrm{LH}$. This explanation receives support from the observations, reported here, that oöcytes from a significant percentage of follicles injected with $\mathrm{PGF}_{2 x}$ were apparently extruded through the sites of injection, as though forced through this path of least resistance by contractions of the follicle. Additional support for such an explanation has been provided by the recent report of VIRUTAMASEx and FUCHS (I974) describing increased contractile activity of rabbit ovaries beginning 8-9 hours after $\mathrm{HCG}$ injection. Failure of $\mathrm{PGF}_{2 \alpha}$-injected follicles in the present studies to ovulate in the normal manner, i.e., through stigmata on their surfaces, could be explained by lack of proteolytic digestion and weakening of the follicle wall due to absence of I,H. RoNDELI, (I970) has provided evidence that ovarian steroids, e. g., progesterone, may be mediators of this latter response to $\mathrm{L}_{\mathrm{H}} \mathrm{H}$, acting upon proteolytic enzyme (s) within the follicle wall. Further research will be required to unravel the interactions between ovarian steroids, prostaglandins, and possibly cAMP, which lead ultinately to normal orulation in response to $\mathrm{L}, \mathrm{H}$.

$$
\text { Colloque: Control of sexual cycles in domestic animals }
$$
October $2 \%-30,1974$, Nousilly.

\section{ACKNOWLEDGEMENTS}

The collaboration of Drs. J. Robixsox, Y. S. Moon, J. Zavecxlk, D. L. Grinwich, T. G. Fexxeny and J. H. DorRisgtox in various phases of this work is gratefully acknowledged. The research was supported by grants from the Vedical Research (ouncil (Canada) and the Ford Founration (I. S. A.).

\section{RÉSUMÉ}

RÔLE IES PROSTAGIANINNES INANS I,ES RÉPONSES FOIIICUI,AIRES A I.H

Il a été trouvé que les niveaux de prostaglandines de la série $F$ augmentent plusicurs fois pendant la période préovulatoire dans les follicules de Lapines, de Rattes et de Truies ; les niveaux maximum sont atteints peu avant l'ovulation. Chez la Lapine et la Ratte, l'augmentation peut être provoquée par de l'hormone lutéinisante exogène $(\mathrm{LH})$. Cette augmentation chez la Ratte est précédée par un accroissement des niveaux ovariens d'AMP cyclique et de progestérone. L'administration systémique d'indométhacine empêche l'augmentation de prostaglandine $\mathrm{F}$ au niveau ovarien et bloque l'ovulation chez la Lapine et la Ratte. L'injection intrafolliculaire d'indométhacine chez la Lapine à des doses inefficaces par voie générale bloque l'augmentation des prostaglandines folliculaires ainsi que l'ovulation. L'antisérum anti-PGF ${ }_{2} \alpha$ bloque aussi l'ovulation quand il est injecté dans le follicule. L'injection intrafolliculaire de $\mathrm{PGF}_{2 \alpha}$ chez la Lapine provoque, en l'absence de LH, la libération de l'ovocyte chez $40 \mathrm{p}$. Ioo des follicules injectés et une reprise des divisions méiotiques de l'ovocyte dans $90 \mathrm{p}$. I oo des follicules injectés. La prostaglandine $\mathrm{E}_{2}$ est beaucoup moins efficace. Ces résultats sont en faveur d'un rôle physiologique de la $P G F_{2 \alpha}$ folliculaire dans les processus d'ovulation et de maturation ovocytaire en réponse à $\mathrm{L} H$.

\section{REFERENCES}

Ainsworth J., Baker R. J), Armstrong J). T., I975. Prostaglandins (manuscript submitted).

Armstrong 1). T., Grinwich D. L., 1972. Blockade of spontaneous and L.H-induced ovulation in rats by indomethacin, an inhibitor of prostaglandin biosynthesis, Prostaglandins, 1, 21-28. 
Armstrong I). T., Grinwich D. L., Moon Y. S., Zamecnik J., 1974. Inhibition of ovulation in rabbits by intrafollicular injection of indomethacin and $\mathrm{PGF}$ antiserun. Life Sci., 14, I29-140.

Armstrong D. T., Moon Y. S., Grinwich D. L., I973. Possible role of PGs in ovulation. $A d r$. Biosci, 9, 7o9-7I 5 .

Armstrong D. T., Moox S. Y., ZAMEcnik J., I974. In : Gonadotropins and gonadal function, N. R. Movdial, editor, Academic Press, New York pp. 345-356.

Armstrong D. T., Zamecnik J., I975. Mol. and cell. Endocrinology (in press).

Ellsworth L. R., Armstrong D. T., I974. Effect of indomethacin and 7-oxa-13 prostynoic acid on luteinization of transplanted rat ovarian follicles induced by LH and $\mathrm{PGE}_{2}$. Prostaglandins, 7, I65-I74.

Gilman A. G., 1970. A protein binding assay for adenosine 3', 5'-cyclic monophosphate. Proc. Nat. Acad. Sci. U.S. A. 67, 305.

Grinwich D. L., Kennedr T. G., Armstrong I). T., 1972. Dissociation of ovulatory and steroidogenic actions of luteinizing hormone in rabbits with jndomethacin, an inhibitor of prostaglandin biosynthesis. Prostaglandins, 1, 89-96.

Jones E. E., Nalbandov A. V., I972. Iiffects of intra follicular injection of gonadotropins on ovulation or luteinization of ovarian follicle. Biol. Reprod., $y, 87-93$.

Kolena J., Channing C. P., ig72. Stimulatory effects of LH, ISSH and prostaglandins upon cyclic $3^{\prime}, 5^{\prime}$-A.IP levels in porcine granulosa cells. Endocrinology, 90, $1543^{-1} 55^{\circ}$.

Kuehl F. A., Humes J. L., Tarnoff J., Cirillo V. J., Ham I. A., I97o. Prostaglandin receptor site : evidence for an essential role in the action of LH. Science, 169, 883-886.

Lemaire: IV. J., Yang N. S. T., Behrman H. R., Marsh J. M., I973. Preovulatory changes in the concentration of prostaglandins in rabbit graafian follicles. Prostaglandins, 3, 367 (Abstract).

Orczik G. P., Bhhrman H. R., I972. Ovulation blockade by aspirin or indomethacin. In vivo evidence for a role of protaglandin in gonadotropin secretion. Prostaglandins, 1, 3-20.

Rondell P., 1970. Follicular processes in ovulation. Fed. Proc., 29, 1875-I879.

TSAFRIRI A., KoCH Y., LiNDNER H. R., I973. Ovulation rate and serum LH levels in rats treated with indomethacin or prostaglandin $\mathrm{E}_{2}$. Prostaglandins, 3, 46I-467.

TSAFRIRI A., LiNDNER H. R., ZOR U., LAMPREChT S. A., I972. In vitro induction of meiotic division in follicle-enclosed rat oocytes by LH, cyclic AMP and prostaglandins $\mathrm{E}_{2}$. J. Reprod. Fert., 31, 39-50.

VANE J. R., I97r. Inhibition of prostaglandin synthesis as a mechanims of action for aspirin-like grugs. Nature Vew Biol., 231, 232.

Virutamasex P., Fuchs A. R., 1974. Proc. Seventh annual Meeting, Soc study of reproduction. Ottawa, Canada, p. 94.

Zamecick J., Armstrosio D. T., 1973. Proc. Can. Fed. Biol. Soc, 16, 29. 